\title{
Land Abandonment in Mountain Areas of the EU: An Inevitable Side Effect of Farming Modernization and Neglected Threat to Sustainable Land Use
}

\author{
Thomas Dax ${ }^{1, *(\mathbb{D})}$, Karin Schroll ${ }^{1}$, Ingrid Machold ${ }^{1}\left(\mathbb{D}\right.$, Martyna Derszniak-Noirjean $^{2}$, Bernd Schuh ${ }^{2}$ and \\ Mailin Gaupp-Berghausen ${ }^{2}$ \\ 1 Federal Institute of Agricultural Economics, Rural and Mountain Research (BAB), Dietrichgasse 27, \\ A-1030 Vienna, Austria; karin.schroll@bab.gv.at (K.S.); ingrid.machold@bab.gv.at (I.M.) \\ 2 Austrian Institute for Regional Studies (ÖIR), Franz-Josefs-Kai 27, A-1010 Vienna, Austria; \\ derszniak@oir.at (M.D.-N.); schuh@oir.at (B.S.); gaupp@oir.at (M.G.-B.) \\ * Correspondence: thomas.dax@bab.gv.at; Tel.: +43-171100-637528
}

\section{check for}

updates

Citation: Dax, T.; Schroll, K.;

Machold, I.; Derszniak-Noirjean, M.;

Schuh, B.; Gaupp-Berghausen, M.

Land Abandonment in Mountain

Areas of the EU: An Inevitable Side

Effect of Farming Modernization and

Neglected Threat to Sustainable Land

Use. Land 2021, 10, 591.

https://doi.org/10.3390/land10060591

Academic Editors: Rob Marchant and Aida Cuni-Sanchez

Received: 10 May 2021

Accepted: 1 June 2021

Published: 3 June 2021

Publisher's Note: MDPI stays neutral with regard to jurisdictional claims in published maps and institutional affiliations.

Copyright: (c) 2021 by the authors. Licensee MDPI, Basel, Switzerland. This article is an open access article distributed under the terms and conditions of the Creative Commons Attribution (CC BY) license (https:/ / creativecommons.org/licenses/by/ $4.0 /)$.

\begin{abstract}
In a period of rising concern for sustainable land management systems to achieve food security at a global scale, land-use changes demand increased attention. This study assesses the past observations and future risk calculations for land abandonment across European regions, highlighting the particular risk for mountain areas. It draws from a study commissioned by the European Parliament to investigate the situation and probability for high and very high risk of land abandonment until 2030. Revealing that land abandonment is at three times higher risk in mountain areas than in non-mountain areas, the need for action to cope with this pressure is the core result. We reveal that the high disparity in agricultural competitiveness between regions (at fine geographical scale) is the main driving force leading to the spatially uneven performance of land management. Viewing this wide set of drivers and mitigation options, land abandonment is understood as the outcome of a multitude of factors of socio-ecological systems and a combination of farm-specific, internal regional and trans-regional factors. The present dominance of narratives of effectiveness leaves little scope for mountain regions under threat of abandonment and marginalization. In this situation, policy reform would address the issue but this might turn out to be influential only if the complex nature and trade-off of the comprehensive policy framework are prioritized.
\end{abstract}

Keywords: land-use change; land management; spatial effects; small-scale context; socio-economic drivers; policy assessment; CAP; policy trade-offs; mitigation policies

\section{Introduction}

In a period of rising concern for sustainable land management systems to achieve food security at a global scale, land-use changes demand increased attention. However, these are not merely linked to quantitative aspects of food provision, but inherently refer to the beneficial effects linked to socio-ecological systems of primary production. The threat of neglecting such crucial issues of food and forestry production is at the core of current discussions about how to realign dominating features of sector activities and respective policies [1] with sustainable development goals. Over past decades, with the emergence of agricultural surplus and due to the high divergence of farming conditions, productivity and viability, more and more agricultural land have become fallow land and are regarded as "abundant" for market production. This process has led to land abandonment processes in almost all European countries [2]. Due to the wide scope of drivers, it occurred gradually at the plot level and was felt particularly at local scales, thus hampering general recognition and awareness of the phenomenon.

Following deep concern over the concentration of agricultural production $[3,4]$, the impacts of modern agribusiness on the cultural basis of farming and its close relationship 
with place-specific land-use systems [5], land abandonment was an early issue of farm modernization prospects. As early as in the 1970s, agricultural policies in the European Economic Community (EEC), but also in several European countries (Switzerland, Austria, Norway), recognized the limited farmland viability in certain regions and created policy instruments for "less-favored areas" to cope with these challenges [6]. In the initial concept of that policy, it was understood as a farming system under threat, being particularly "marginalized" and prone to lose, with the ongoing land abandonment, its viability and functions for the society [7]. The ongoing technological developments and market changes further increased apprehension about the continuation of land management, and through it, the preservation of positive environmental and socio-economic benefits of agricultural activities [8] in these "disadvantaged" areas.

Pressure for giving up land further increased due to continuous productivity increases and the intensification of agriculture. However, propensity for land abandonment is not equally distributed across the regions, land types and management systems of the EU [9]. While these processes of land use are not exclusive to European regions, the legacy of place-specific land-use patterns marked by significant diversity in land cover and land management is particularly strong here. Moreover, it is historically linked to rural livelihood features that translate to both high attachment to the specific regions and attractive assets seen in those "rural amenities" by non-rural populations and visitors from other areas. Rural amenities are thus seen as strongly enhancing tourism development (of different forms) in close relationship to specific land-management systems [10].

Studies on transitions of land management regimes over long time periods recognize the ongoing but uneven intensification process of agricultural land use and urban growth. Jepsen et al. [11] observe that science has traditionally addressed mainly the spatial determinants of land-use change, neglecting, to some extent, the array of other aspects influencing land-use decisions. Moreover, as historical data are often unavailable, the periods of land-use change observation tend to be short and might overlook the influences of contrasting and interrelated drivers of land-use change. Despite large-scale processes of industrialization across European regions, high path dependency preserved a "marked spatial heterogeneity in land-management regimes" until around 1950 [11] (p. 63). Since then, periods of collectivization, intensification, de-intensification and commercialization and rising environmental awareness have led to divergent and spatially very different developments. A recent study of land-use change across Europe depicts the substantial loss of utilized agricultural area (UAA) over recent periods [12]. This overall trend is linked to three main components:

- Gaps in land rent between settlement areas and agricultural areas are so high that economic valorization stimulates the conversion of agricultural land into artificial land use. Urbanization and urban sprawl are not restricted to agglomeration areas but reduce UAA, also within rural regions.

- On the other hand, UAA is converted into forests. Such land-change processes are observed primarily for areas where agriculture is economically challenged, and afforestation may be part of an agricultural extensification strategy.

- Beyond those two, clear-cut trends of general land-use change, productivity increases and changes in regional competitiveness of agricultural production might lead to gradual adaptation in the production structure, and spatial concentration of production. As a result, agricultural land use of some farmland might be ceased, depending on a series of local and individual factors.

While the general land-use changes toward urbanization or afforestation are obvious trends, the critical phenomenon of land abandonment may be mostly linked to the third aspect. It is captured by the formulation in the recent Joint Research Centre's (JRC) study, providing the following most commonly used definition of land abandonment: According to the authors it "refers to land that was previously used for crop or pasture/livestock grazing production, but does not have farming functions anymore (i.e., a total cessa- 
tion of agricultural activities) and has not been converted into forest or artificial areas either" [12] (p. 1).

Analyzing the causes and main influences on land abandonment processes requires facing contrasting land-change tendencies across spatial units. What is more, trends might be divergent for small, medium and large scales, pointing to a diverse relevance of drivers for different areas and levels. Thus, understanding land abandonment as "a complex multi-dimensional process with interlinked economic, environmental and social aspects" [13] (p. 2) implies its heavy impact on regional sustainability pathways [14]. While its occurrence and relevance are particularly linked to specific and changing spacetime contexts [15], many studies acknowledge a wide range of influencing drivers and a high degree of interrelated factors impacting land managers' decisions [13,16-18]. With the rising concern for food security at a global scale [19] and the rising focus on food sovereignty $[20,21]$, the loss of agricultural land has become a crucial issue in many regions. The increased attention is palpable through a number of case-specific and comparative studies at the European scale [22], highlighting the great diversity of drivers and trajectories in various spatial contexts (for example, explored in another Special Issue of this journal, Land [23]). They reveal that a complex interplay of a wide set of "sociodemographic, economic, technological, policy and institutional factors but also cultural factors may drive (land) abandonment" [23] (p. 4).

Even if these studies regularly underpin that landscape changes are highly dependent on specific political, institutional, economic, cultural, technological, natural and spatial factors as drivers [24], there is a conspicuous spatial pattern for land-abandonment processes. Comparative monitoring of the extent of past changes and model calculations of impending land abandonment risk [12] point to mountain areas as specific, remote locations that are particularly affected. They underline that land abandonment has to be seen as "a complex multi-dimensional process with interlinked economic, environmental and social aspects" [13] (p. 2) that plays out in areas of natural constraints much more than in other small areas limited in their production capacity by local biophysical or other development conditions.

It is a main research hypothesis that a spatially differentiated view to focus on land use and landscape development is required, and analyses on the implications for mountain areas are a priority concern where land management challenges cumulate.

With a focus on the complex set of socio-economic pressures on mountain economic activities and living conditions in those regions, the particularly high-risk level is no surprise. Klein et al. [25] provide survey data from 57 mountain 'socio-ecological systems' from all parts of the world and reveal similar and diverse problem patterns and opportunities across these mountain locations. In terms of land change, there is a high degree of stressors and challenges for ecosystem services provision observed in many respects [26]. Highlighting the particular, large array of pressures but also a simultaneous, large scale of mountain-specific opportunities, these tensions are framed as 'paradoxes' that create substantial challenges for sustainable development options. As a specific concern, land abandonment may be more pronounced in areas with limited production capacity and productivity, e.g., in areas facing natural constraints (ANC). In particular, agriculturally less-favored areas, such as mountain areas, islands and other remote parts of Europe, are reported to face significant challenges in retaining vital farming structures and have long been confronted with a steady decrease in agricultural land use [27]. Location in socio-economically disadvantaged areas add to these "handicaps", impeding swift market integration, access to value chains or networks. Instead, the focus is on niche development and innovative, quality schemes of mountain products [28,29] and the elaboration of specific mountain value chains [30] to bypass unfavorable challenges of mass production and remoteness. However, land abandonment is not only a sector issue, but has wider implications for societal development, ecological performance, and the rural fabric [31]. As farm holdings with reduced viability prospects are often regarded as particularly prone to abandonment processes, particularly wide-spread, small-scale structures (e.g., in Southern 
or Eastern Europe) could aggravate negative regional performance of the whole economy and contribute to demographic decline, often referred to as 'shrinking rural regions' due to the long-time persistence of downward trends [32].

In many remote and mountain contexts, the progressive reduction in farm numbers and agricultural land use has implied a loss of important landscape features and ecological performance [7]. This structural change has been accompanied by agricultural land abandonment in substantial parts of the EU's rural regions. Particularly, the focus on intensive land management systems has propagated these adverse effects and is adding to the pressures experienced in low-productivity areas such as the mountains. Any strategy to cope with abandonment aspects need to address the balance of intensive and extensive areas, and the capacity to achieve a shift toward sustainable production management systems, including the spatially uneven potentials and capacity to shift toward sustainable pathways.

Scale and location are thus crucial considerations when assessing the drivers, as well as the effects (both negative and positive) of land abandonment. In this paper, we focus on the large-scale observations of land abandonment for mountainous areas, as these are primarily affected by the ongoing tensions and for decades have been threatened by these processes. We begin by synthesizing quantitative model results on risk assessment across the EU and revealing the particularly high threat for mountain regions. The strong pressure on land-use change is linked to a wide set of drivers, implying the effects of natural constraints for land uses and harmful effects to other sectors. In the discussion, emphasis is put on highlighting the dichotomous trends in land management, favoring a continuous orientation toward competitiveness without responding adequately to rising social and ecological challenges. This will be taken up in the conclusion to underpin the necessity to review existing policy frameworks and the implications of ongoing landuse trends of mountain regions, expressed, in particular, through exacerbated levels of land abandonment, on ecological performance, landscape development and the specific amenities of those areas.

\section{Materials and Methods}

The paper builds on a study that was commissioned by the European Parliament to provide a deeper and up-to-date understanding of land abandonment in the EU based on available data and information, including its development, drivers, mitigating measures across EU policies, not limited to the EU's Common Agricultural Policy (CAP) and respective scenarios [22]. The resulting report was provided to assist the members of the Committee on Agriculture and Rural Development (AGRI Committee) of the European Parliament in discussing the legislative proposals regarding CAP post 2020, including the Commission Communication and Action plan on "A long-term vision for Rural Areas", expected in 2021. Its scientific assignment was to complement existing evidence with specific research on land abandonment to differentiate trends of diverse land management systems and types of regions, and to draw conclusions relevant to policymaking regarding the post-2020 CAP policy [33]. This paper retrieves spatial information relevant for mountain area trends and highlights the particular affectedness of this type of region for land-abandonment risk.

With a view on assessing the pace and occurrence of land abandonment across mountain regions in Europe, the paper benefits from an intensive literature review on studies exploring both general trends and the differentiation of land-use change at a fine geographical scale within mountain areas. It is particularly necessary to include the fine-grained internal divergence of mountain contexts where abandonment and intensification of various uses might take place in closely adjacent areas. Moreover, trends are quite different from mountain range to mountain range, and thus any large-scale appraisal should point to these internal divergent and context-specific developments [34]. The analysis is based on quantitative data used by the Joint Research Centre (JRC) of the European Commission [12] as well as other data sources, such as Corine Land Cover data for land use change. These data are the basis for further quantitative and qualitative analyses. In particular, GIS analy- 
ses and quantitative analyses, such as Naïve Bayes classifier [35], were applied to provide different geographical resolutions of land abandonment and define groups of regions with specific regional characteristics. This also resulted in probability checks for increased risk level of mountainous areas due to these data sources. Qualitative data collection and analysis via desk research, four case studies in diverse European regional contexts, and expert interviews complemented the statistical database, particularly to take account of the multiple set of drivers impacting land use and change in management decisions. This also provided input to scenario building on future development perspectives with regard to land abandonment outcomes. The results from specific case study exploration and scenario building are presented here only in relation to mountain development aspects, as contextual aspects are highly uneven between specific geographical places.

Quantitative and qualitative assessments of land abandonment trends and influencing aspects were also analyzed against a review of CAP instruments and their implications, both favoring and disfavoring aspects of abandonment and future scope to address challenges of sustainable land-use pathways. This appraisal mainly reflects the large-scale European perspective and would need place-sensitive investigations for differentiating implications on individual regions. Methodological issues have strong implications for the resulting effects in CAP reform discourse and policy framework outcomes. Many analysts underpin the need for more place-specific commitment in policy reform, a stronger need for shifts in policy objectives toward integrating climate-change needs and ecological challenges [36] and addressing more actively agroecological approaches in the future policy [37].

\section{Elevated Risk of Land Abandonment in Mountain Regions}

The description of observed trends of land abandonment supports the assumptions for the stronger relevance of the issue within mountain areas. In the first part of this section, the respective quantitative assessment of risk calculation (at different levels) is presented in a comparative manner between mountain and non-mountain areas of the EU28 , and for different mountain ranges within the EU. This analysis is then supplemented by a discussion of the driving forces for this spatial feature of land-use change and an assessment of policy framework addressing this challenge.

\subsection{Risk Assessment in Mountain Regions of the EU}

The analysis focuses on the survey presentation of the status and trends of quantitative development of land abandonment for all countries of the EU and differentiation by regions and geographical types. Building on the long-term concern of land-use changes across European regions [38], the cumulative effects of concentration and abandonment trends are analyzed. With regard to mountain areas, a comparative view against the situation in non-mountain areas reveals significant differences in threats experienced in mountain contexts. Analyses at the NUTS-3 regional level (nomenclature of territorial units for statistics) show that the higher the share of mountainous areas, the higher the risk of land abandonment (and vice versa - the higher the share of non-mountainous areas, the smaller the risk of land abandonment as shown in Figure 1).

The relationship is presented against five classes of regions, ranging from very low characteristics of mountain areas (less than $20 \%$ of total area to be classified as mountainous) to very high area shares (of more than $80 \%$ of mountainous areas). These classes are matched with the probability of regions belonging to different risk levels of land abandonment. Similar to geographical classes, the risk level is also grouped into five classes (labeled as "very high, high, moderate, low, very low" probability of risk). From the model output (Table 1) the probability of regions belonging to either a high or even a very high risk of land abandonment attains more than $50 \%$ for regions with a very high share (more than $80 \%$ ) of mountainous areas. The strong correspondence of a high share of mountain areas and a high share of risk is underpinned by the respective results for other classes. In mixed regional contexts, moderate risk levels prevail but these might also appear for 
regions with low mountain profiles where aspects other than geographical specificity (e.g., structural features) might prevail as influencing aspects.

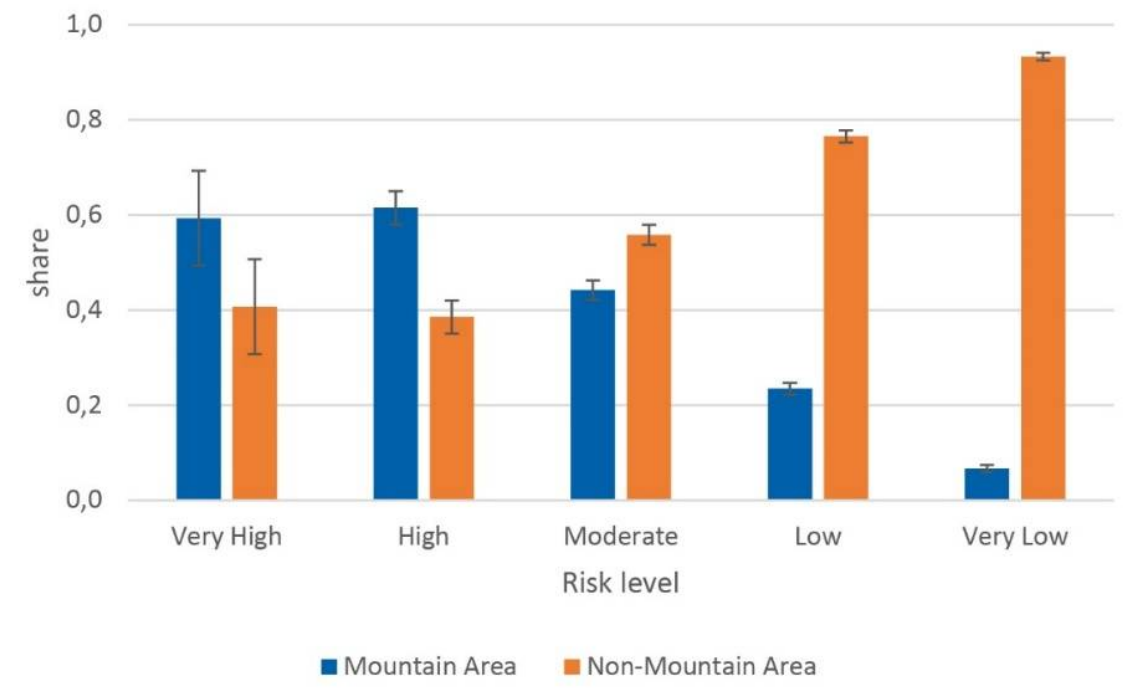

Figure 1. Average share of five risk levels for mountain and non-mountain areas in EU.

Table 1. Conditional probability ${ }^{1}$ of mountainous areas in EU per risk level.

\begin{tabular}{cccccc}
\hline $\begin{array}{c}\text { Share of } \\
\text { Mountain Areas }\end{array}$ & $\begin{array}{c}\text { Very High } \\
\mathbf{( > 8 0 \% )}\end{array}$ & $\begin{array}{c}\text { High } \\
\mathbf{( 6 0 - 8 0 \% )}\end{array}$ & $\begin{array}{c}\text { Moderate } \\
\mathbf{( 4 0 - 6 0 \% )}\end{array}$ & $\begin{array}{c}\text { Low } \\
\mathbf{( 2 0 - 4 0 \% )}\end{array}$ & $\begin{array}{c}\text { Very Low } \\
(<\mathbf{2 0} \mathbf{0})\end{array}$ \\
\hline Risk level (\%) & & & & & \\
Very high & 0.545 & 0.0455 & 0.0455 & 0 & 0.364 \\
High & 0.511 & 0.145 & 0.046 & 0.015 & 0.282 \\
Moderate & 0.169 & 0.266 & 0.162 & 0.052 & 0.351 \\
Low & 0.012 & 0.055 & 0.210 & 0.232 & 0.491 \\
Very Low & 0.017 & 0.005 & 0.019 & 0.061 & 0.898 \\
\hline
\end{tabular}

${ }^{1}$ Based on DEGURBA data from EUROSTAT (2019), calculation based on model output by Naïve Bayes classifier. Source: [22] (p. 33).

The model results for the various classes of mountain regions so far presented focus on the European assessment, on average. To understand and grasp the actual local situation, geographical differentiation and fine-grained spatial attribution are required. In the first instance, data for the main mountain ranges in Europe are reported in Table 2, highlighting the great variance of risk levels between these contexts. From this overview, the high incidence for risk in mountain ranges, in general, can be deducted $(20.5 \%$ of high or very high risk in mountain areas vs. $7.7 \%$ in non-mountainous areas) and at the same time, the specific relevance for several mountain ranges particularly affected can be observed. In particular, the Eastern Mediterranean Islands and the Alps are affected by a specifically high degree of risk level. Such diverse contexts, such as the Balkan mountain regions and those of the British Isles, show substantial shares of high or very high risk levels. In interpreting these results for mountain ranges, we have to acknowledge that these comprise large areas and thus might include quite different internal divergences. To some extent, we might delineate the very wide-spread relevance of medium risk for almost all mountain ranges across Europe, thus indicating that geographical features of mountains might induce factors for increasing risk levels. In most mountain ranges, this class is relevant for more or less than half of the respective space (at EU-28, average $42.9 \%$, and for non-mountain areas, just $21.8 \%$ ). 
Table 2. Risk for land abandonment in European mountain ranges (in \%).

\begin{tabular}{lcc}
\hline \multicolumn{1}{c}{ Mountain Range } & Medium Risk & High/Very High Risk \\
\hline Alps & 42.7 & 46.6 \\
Apennines & 56.7 & 13.0 \\
Balkans/Southeast Europe & 34.0 & 29.3 \\
British Isles & 27.0 & 29.6 \\
Carpathians & 58.7 & 21.7 \\
Central European middle mountains 1 (BE + GE) & 35.9 & $3.0^{1}$ \\
Central European middle mountains 2 (CZ; AT; GE) & 28.2 & $9.3^{1}$ \\
Eastern Mediterranean islands & 41.8 & $58.2^{1}$ \\
French/Swiss middle mountains & 26.7 & 17.9 \\
Iberian mountains & 46.4 & 16.1 \\
Nordic mountains & 49.6 & $5.7^{1}$ \\
Pyrenees & 39.2 & $14.8^{1}$ \\
Western Mediterranean islands & 67.5 & $13.5^{1}$ \\
\hline Mountain areas (EU-28) & 42.9 & 20.5 \\
Non-mountain areas (EU-28) & 21.8 & 7.7 \\
\hline
\end{tabular}

${ }^{1}$ Only high risk observed in this mountain range. Source: [22].

The results correspond to the findings of many case-specific studies on selected regions that observe the high incidence of land abandonment in mountain areas $[7,9,27,39-43]$ and underscore the particular risk for future developments [9,44,45].

As risk of land abandonment is variable at low geographical detail, presentation in an overview map for the European situation requires applying a more large-scale unit level. The respective map (Figure 2) summarizes findings from a model calculation by the JRC study [12] and depicts the average risk level at the NUTS-3 average, ranging from very low (green color) to very high (dark red color). It reveals the particular relevance of land-abandonment risk for mountain regions of Europe in comparison to lowland areas, which are, to a large extent, characterized by very low or low risk levels. Exceptions from this general picture are visible for remote regions in Scandinavia, Baltic countries and Eastern border regions of EU New Member States. On the other hand, most large-scale mountain ranges dispose at least moderate, if not high or very high, risk levels. This very crude visualization of spatial distribution of the land abandonment challenge underpins the general appearance of land-use changes at a high level. It should be emphasized that place-specific, local influences might lead to locally very different effects and internal divergent trends within small distances. Community development analyses, such as those for a Tyrolean municipality [43], might be accessed as instructing examples for this phenomenon. These fine-grained territorial differences link to the need to understand the driving processes of land abandonment more comprehensively, an aspect which is explored in detail in the following section. 


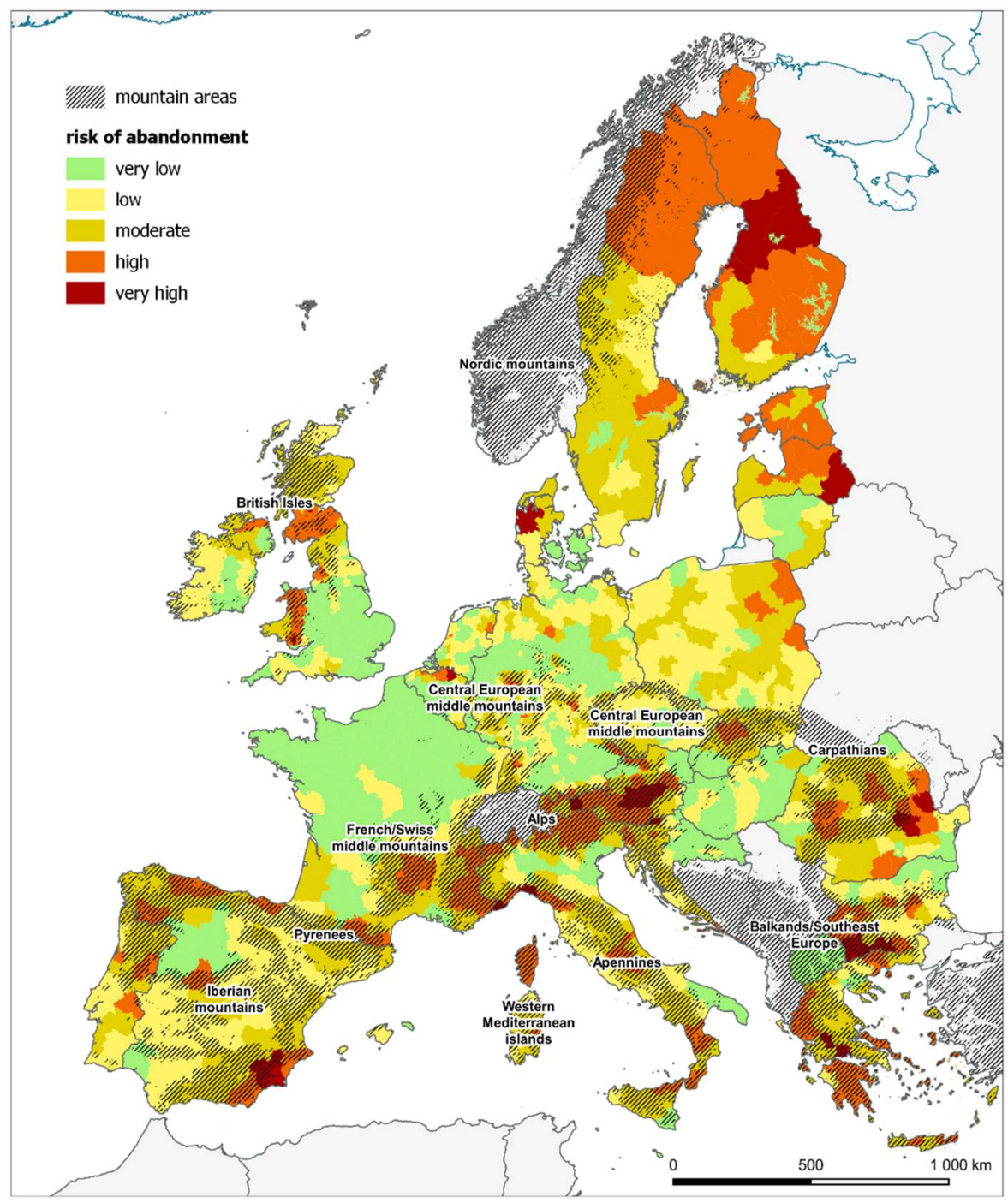

Figure 2. Risk of land abandonment at the NUTS 3 level and mountain areas.

\subsection{Drivers and Policy Framework to Respond to Land Abandonment Challenges in Mountain Areas}

The significant changes for land use and risk for land abandonment addressed for mountain areas across Europe are the result of a highly diverse set of influential forces impacting land use in these areas and the relative developments of land management with regard to other, more favored agricultural areas. In assessing the main drivers for the regional development of land use, it seems crucial to frame the analysis in such a comparative view. Without taking into account developments in other regions, any analysis would fail to incorporate the full set of contributing forces for land abandonment.

These large-scale, systemic aspects are at the core of many previous studies, which underscored both the scope of different factors impacting the amount and specific areas used for agricultural purposes within a particular area, and the diverse orientation of effects. It seems important to underscore that for some bundles of indicators, reinforcing effects (for others, contradictory effects) and various types of mixed effects might occur. Perceiving pressures on land use and the resulting changes in landscapes in specific geographical areas such as mountain regions, particular concern for shifts in spatial features and functions has been raised over past decades [7]. Accompanying the policy commitment to address the foundations for land management decisions, a wide array of influencing aspects have been discerned. Even if the complexity of drivers is widely acknowledged the details of cause-effect relationships, triggering events and action, the scale of implications and 
interrelations, and the relative dependencies between different spaces and land use and land management systems remain largely unclear at a general level. Beilin et al. [46] reveal in their analysis of agricultural land abandonment across diverse bio-physical regions (Sweden, Portugal and Australia) that historical trajectories of land cover change and the relative importance of each driver and its scale of action might have a different impact for future trends. "Pressures and attractors encouraging agricultural abandonment" would, thus, depend significantly on that study on place-specific features of the interplay of land management and social and institutional aspects.

Investigating the main drivers of land abandonment at the EU level relies, therefore, on a good understanding of the variability of influential factors, their relative weight, complementary or reverse effects and the complexity of cause-effect chains. This seems particularly pertinent in spaces that are experiencing challenges for competitiveness and productivity of land management systems, such as mountain regions. As the specific problem patterns of these areas are key for future land-use decisions, it is crucial to include an analysis of the interplay of non-land management based regional activities, economic uses and service provision with the organization and trends of land-use persistence. This view extends also to consider widespread environmental degradation trends, increasing land-use conflicts, and actors and triggers in complex socio-ecological systems [47]. Such a comprehensive perspective on ecological and regional contexts implies an in-depth account of rural areas' perspectives and the role of strategies to enhance the viability of rural regions. The preparation of the Communication on the Long-Term Vision of Rural Areas (LTVRA) by the European Commission [48], to be approved in mid-2021, sets out an appropriate action plan and demands commitment for inspiring local and regional activities with significant knock-on effects for land abandonment implications.

A number of studies assessing the features and causes of land abandonment $[7,11,14-16,49,50]$ have contributed to elaborating a wide set of drivers. which are presented in groups in Figure 3. As the interrelations in the presentation underpin, there are complex interactions between these groups of drivers and between every single impacting factor as well.

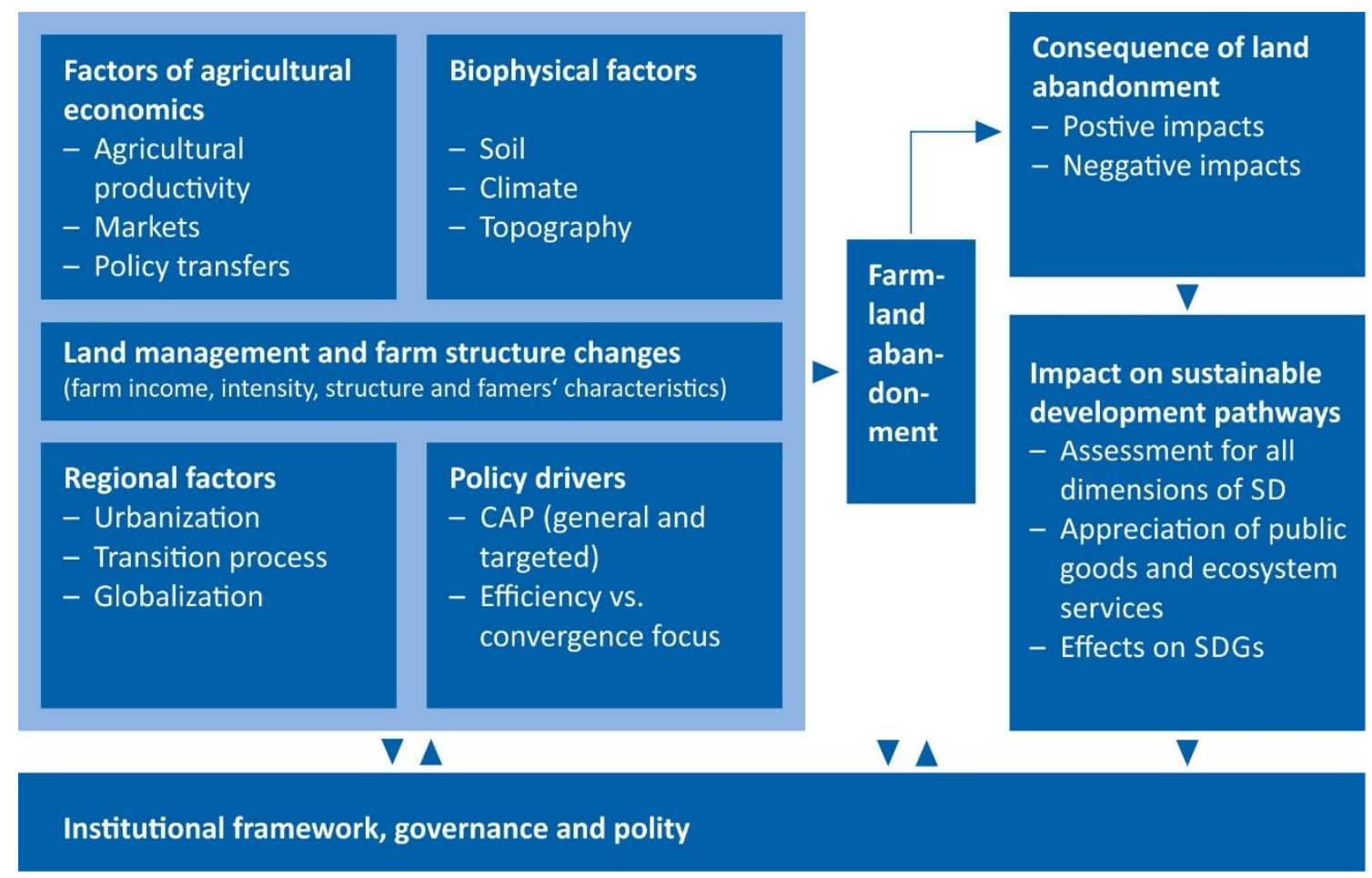

Figure 3. Drivers of land abandonment and integration into sustainable development pathways. Source: Modified from [14] in [22]. 
The interactions addressed emphasize how land abandonment is dependent not just on biophysical aspects, management strategies and agricultural market conditions, but also on economic development, socio-cultural drivers, and regional and institutional aspects. Despite the wide array of factors influencing land abandonment, management issues and structural adaptation remain key driving forces. The complex nature of linkages between these primary, internal drivers and the aforementioned large-scale, mainly external triggers contributes to the difficulty of observing land-abandonment processes [15]. Moreover, assessment is exacerbated when geographical specificities add restricting requirements through limited access and institutional weaknesses. Sectoral approaches might limit a reflected position on the core role of governance frameworks to address the facilitating role of local and regional actors in coping with marginalization and abandonment issues [51,52].

Deficiencies of mountain areas to address and mitigate these effects in the shortterm underpin the long-term nature of land-use adaptation processes. In particular, this is related to the under-provision of highly demanded public goods that are linked to specific land management types, related to region-specific land use systems, such as lowintensity grassland, pastures and mountain meadows. 'Paradox' captures are increasingly experienced in these contexts [25]. The need for including local actors in "planning to envision mountain socio-ecological systems" [53] to realize place-sensitive management schemes is often hampered by failures in institutional settings and inadequate policy frameworks. In 'marginal' areas, land-use systems tend to be limited [54]; hence, the pressure on policy regulations to secure public goods provision is pervasive. As these values are not adequately recognized in current support mechanisms, there is a need for a 'step change' in CAP policy [55] to 'correct' policy failure.

This need to revise the agricultural policy framework touches a crucial issue of reorienting the CAP policy outline and the implementation to address, from top-down, the risk of falling short of providing an effective and sufficient scope for instruments addressing ecological needs and, particularly, mitigating the detrimental effects on land management, implicating higher levels of abandonment [56] (p. 20). It seems particularly crucial to address ecological needs and the diversity of place-sensitive agricultural systems through shaping land management adaptation in different spatial contexts [36]. In this vein, it is, moreover, argued that failure to "remunerate(e) farmers for all the services they provide could lead to land abandonment and closed landscapes" [56] (p. 26). These gaps in the policy setting are particularly distinct in relation to policies for ANCs, permanent grassland or support for organic farming systems, as well as with regard to the biodiversity strategy and nature protection approaches [56] (pp. 38 and 61).

In assessing the policy framework addressing the wide range of drivers, it appears decisive that general European policy instruments might provide an important, basic framework, which is, however, not sufficient for addressing the multiple threats to which mountain areas are exposed when aiming at mitigating land abandonment trends. Even if implementation details address local specificity and relate to particular development options or obstacles, the orientation and effectiveness of policy instruments should be differentiated by their scale of impact. Figure 4 matches the scale of policy application with the diverse intervention programs. It indicates the crucial farm level (farm unit and even parcel unit) which many instruments of CAP Pillar 1 address by shaping fundamental aspects for market integration and individual management decisions [18]. Space specificity is core here, and has long been a building block of CAP. In particular, the less favored area (LFA) scheme, which aimed at (partly) 'compensating' relatively low competitiveness chances [57] and simultaneously addressing demographic and ecological problems and opportunities of rural areas [6], is the long-term leading instrument in this respect. The evolving policy discourse revised its orientation and refocused its remit much stronger toward its core function to cope with its characteristics of ANCs as it has been termed for several years [58]. However, these instruments, targeted at land managers themselves, need to be complemented by interlinked action at local and regional levels, as well. As the discussion on the interrelated system of drivers suggests, rural economic development, 
environmental performance, human-nature relationships, skills development, educational attainment, enterprise involvement, market chain development and many more aspects, impact on the outcome in land use change and require adapted policy considerations. Beyond that, national and global influences are experienced as a decisive backdrop to many local and regional actions. This underscores the view that land abandonment is embedded in these larger frameworks, which are hardly affected by local management decisions and related policies.

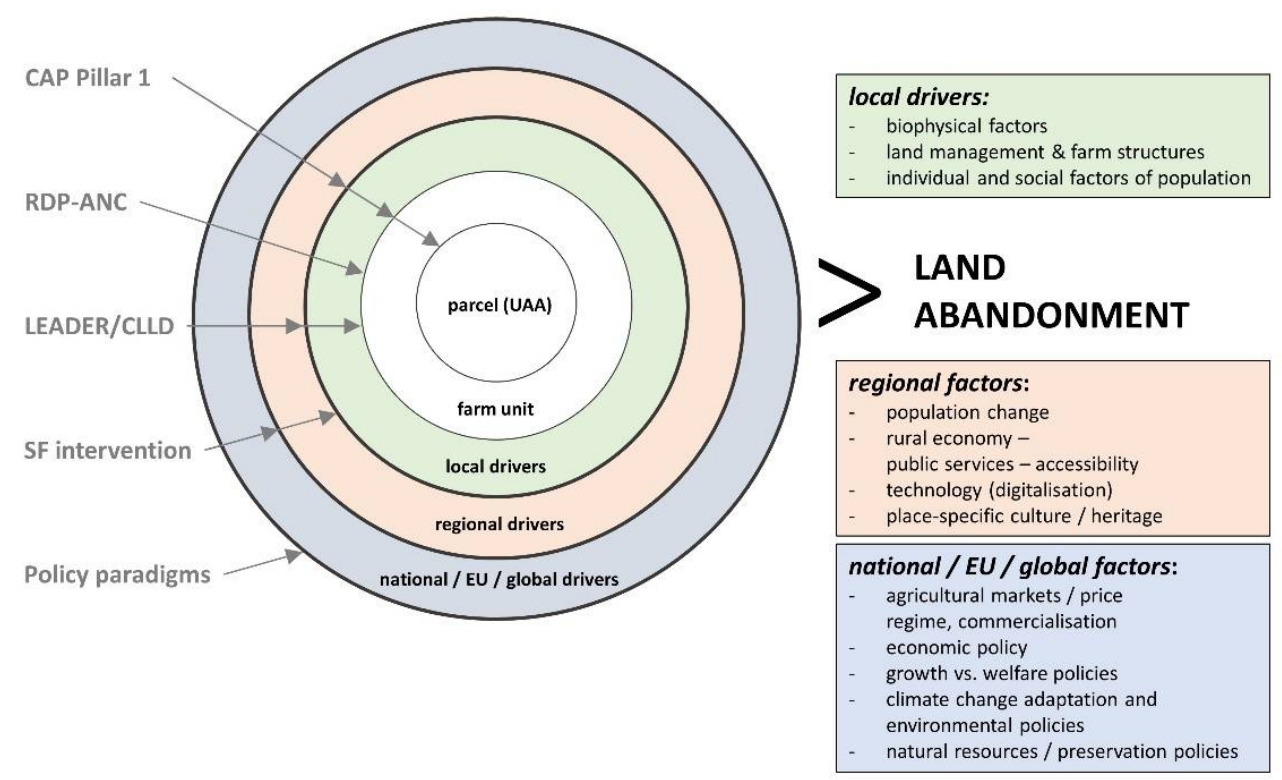

Figure 4. Relevant policies for land abandonment and scales of intervention. Source: [22] (p. 48).

The conceptual framework analyzed for mountain regions is, thus, largely dominated by strong external pressures [25] but also a need for an approach going beyond a simplified, linear, cause-effect relationship as often expressed in monitoring and evaluation practices and concepts of theory of change. As they convey just one plausible development pathway and unique outcomes for specific policy instruments, such views neglect alternative opportunities. We have to conceive the policy arena much more as complex settings of contradictory policy objectives with manifold, unexpected outcomes. Complex evaluation thinking is increasingly addressing these limitations of previous assessment practice, advocating a systemic evaluation design that supports sustainable development pathways [59]. In essence, these approaches are particularly centered on the aspect of how to realign "human and natural system interests (that) too often stand opposed to each other (or outright ignore each other)" [60] (p. 46). Emerging evaluation concepts encompass such an interrelated view of human action effects on natural systems, emphasizing an increasingly intensive array of "contextual conditions and drivers", "baseline assumptions" and scope for intervention design within the socio-political "landscape" [61].

\section{Discussion}

As Lambin et al. [62] explored long ago (2001), viewpoints on causes for explaining land use and land-cover change are often superseded by generalized myths and a simplified perception of cause-effect relationships, as well as potential policy interventions. This also applies to land abandonment analysis in mountain regions. In our analysis of the current challenge of land abandonment in European mountain regions, we aimed to capture the trend that "various human-environment conditions react to and reshape the impacts of drivers differently, leading to specific pathways of land-use change" [62] (p. 266). As abandonment is a highly complex and gradual process, the observation and differentiation for types of areas at the European level are methodologically difficult. Capturing the vari- 
ous steps of initial reduction in agricultural and forestry intensity, and gradual transition toward temporary, transitional and permanent abandonment requires fine, geographical detail, and the process steps usually can only be delineated along specific cases. Past and recent studies have underscored the great variety of processes and diverse sets of influencing drivers, and sector and institutional responses.

As the background study [22] underscores, the pertinence of the problem to secure land management in mountain areas is at the origin of the evolution of important policy instruments [63] and is impacting current discourses of policy reform $[33,36,64]$. The limited effectiveness of related policies points to inherent obstacles and an assessment bias toward the prioritization of farm competitiveness versus other, interrelated policy goals. While respective studies are largely aware of this trade-off, the adaptation of policy and national implementation are adopting such perspectives only by and by. This expert-policypractice tension with regard to face land abandonment pressures in mountain regions as a persistent and trans-boundary problem involves a series of inter-related aspects:

- The large variety of causes for land abandonment across European regions and the methodological complexity in assessing land $\backslash$-use changes and status blur the common and large-scale triggers for long-term underlying trends. Scale aspects and the multitude of drivers contribute to a simplified understanding of areas taken out of management $[9,65]$.

- Although an increased attention to local assets and opportunities of remote and mountain regions is visible, myths about causes are still predominant [62]. These relate particularly to overly generalized views on focusing on the present land use (path-dependency), role of forest areas, urbanization processes and globalization as a unifying, but undervalued aspect.

- Processes of land abandonment, natural successional transition and marginalization in remote regions of Europe lead to a decline in pastures, grassland, and arable habitats as well as an increase in scrub and forests. This implies pressures on high nature value (HNV) farmlands, loss of biodiversity and viability of farm units in these areas [66].

- On the other hand, these re-vegetation trends might improve soil organic matter content, enhance carbon sequestration and contribute to regulating water flow to prevent flooding, particularly in mountain areas $[2,65,67]$.

- Land management in mountain areas is key for providing important ecosystem services for local and trans-regional demand [26]. These functions are represented in public discourse often as public goods $[68,69]$, the specific shaping of features of landscapes and landscape development [47,70-72], securing heritage features of cultural landscapes [73] and the diversity of habitats and biodiversity, thus ensuring place-specific nature contributions to society $[74,75]$.

- While there might also be some benefits from land abandonment due to species reestablishment and the development of new habitat mosaics in mountain regions [16,67], several studies assess that a decline in habitat heterogeneity and species diversity across mountain landscapes is predominant $[9,65,67]$. This is due to the fact that species that benefit from land abandonment are often generalist species of low biodiversity value [76].

- Beyond human-nature relationships, land abandonment in mountain areas is contingent on issues of location (accessibility), cultural heritage and social preference. In particular, prospects for regional performance and transnational perspectives on functions of land use are of decisive influence [77,78].

Large-scale influences are increasingly experienced as persisting pressures for mountain regions [25]. The observed land-use changes and impending risk for land abandonment in this study [22] underpin a long-term concern for viable practices of land management in mountain areas. The spatial dimension of agricultural transformation [79] is particularly driven by spatial concentration processes, due to the intensification of a part of the sector $[4,62]$ leading to regional concentration effects [3] with tremendous consequences for mountain areas. Even within these areas, internal shifts in land use and intensification and 
abandonment processes have to be differentiated [27]. The CAP is shown to pay substantial attention to these challenges in elaborating the dedicated policy instrument of LFA/ANC, which, however, falls short of "compensating" or overcoming the pressures, particularly in remote mountain areas. Much of the remaining policy concern is due to the implicit tradeoffs in the overall policy framework and the limitations of policy action to tackle inherent market mechanisms and socio-ecological frameworks [80]. Therefore, "(p)olicy responses to land abandonment in Europe must move beyond agriculture-oriented schemes under the purview of the Common Agricultural Policy to incorporate a range of independent, holistic rural development programs" [65] (p. 1). Such a perspective advocated by various researchers should be adopted by policymakers to overcome overly narrow agriculturaloriented rural policy, including particularly contextual conditions of mountains, long-term trends of 'rural shrinkage' [32] and human-nature relationships at the core of land-use decisions and outcomes. The current pandemic intensifies these pressures and aggravates the need for diverse, context-specific local support in mountain areas. Ongoing discussions of CAP reform might improve the respective responses, but reluctance to open up to such an encompassing policy framework and regional development practice seems widespread. On the other hand, prospects to turn toward a pathway-enhancing action, inspired by the 'Long-Term Vision for Rural Areas', which is now being initiated, still seems limited.

\section{Conclusions}

Land-use development is not just an issue of adjusting management to local and regional contexts and sector performance, but is dependent on the interplay of all sectors and drivers of respective socio-ecological systems. In providing a comprehensive survey on the experience and future risk for land abandonment, analyzed at various scales and for geographically specific areas, the high incidence for uneven spatial effects becomes clear. Mountains have long been under pressure with regard to maintaining agricultural land management that has increasingly concentrated on extensive grassland systems. This has led to place-specific habitats that dispose of, to a large extent, high nature value farmlands. These consequences present the particular threat arising from the further decrease in managed land within these geographical contexts.

Land abandonment is, however, characterized by a much more complex system of cause-effect relationships and effects. The analysis of a host of diverse studies in the past and our synthesizing study for the European Parliament provide powerful evidence of a combination of many factors for which sometimes, one is predominant over the others. However, in general, mutually reinforcing effects lead to 'spiraling down' processes for land management. These cause-effect chains and threatening outline are particularly valid in mountain regions with high internal differences and specific regional 'hotspots' of abandonment. From current observations and data analyses, there is no ease in this problematic situation in sight for the coming decade.

The main driver for the land-use management and land change prospects are contingent on ongoing intensification processes, due to technological changes and uneven agricultural competitiveness conditions. As long as the approval for a narrative to foster efficiency, technological progress and growth in productivity, i.e., intensity, is the leading paradigm, any strategy to cope with land abandonment and marginalization processes will face almost insurmountable obstacles, as it always would act in a framework of 'compensation'-relative deficiencies in competitiveness.

The deep concern for dealing with the 'failures' or 'restricted impact' of past CAP has spurred concern to reflect the challenge of land abandonment and to revise the agricultural policy framework. It touches on a crucial issue of reorienting CAP policy outline and implementation to address, from top-down, the risk of falling short of providing effective and sufficient scope for instruments addressing ecological needs and mitigating the detrimental effects of land abandonment, particularly in mountain regions. It seems, therefore, necessary to conceive appropriate policy measures beyond CAP, including a comprehensive array of policies with interrelated effects on land management aspects. 
Such a wide scope of policy instruments would include regional and social policies (structural funds), environmental regulation, infrastructural organization and public services for remote regions, and should be addressed also by the recent EC policy reorientation in Green Recovery.

Author Contributions: Conceptualization, T.D. and B.S.; methodology, T.D., I.M., K.S., B.S. and M.D.N.; validation, T.D. and B.S.; literature review T.D., I.M., M.D.-N. and B.S.; formal analysis, M.D.-N., K.S. and M.G.-B.; data curation, M.D.-N., M.G.-B., K.S.; writing—original draft preparation, T.D., B.S., M.G.-B. and I.M.; writing - review and editing, T.D. and B.S.; visualization, K.S., M.G.-B.; synthesis discussion, T.D., I.M., K.S., B.S., M.D.-N., M.G.-B.; supervision, T.D. and B.S.; project administration, M.D.-N. All authors have read and agreed to the published version of the manuscript.

Funding: This research received external funding by the Directorate for Structural and Cohesion Policies of the European Parliament, contract IP/B/AGRI/IC/2020-037.

Institutional Review Board Statement: Not applicable.

Informed Consent Statement: Informed consent was obtained from all subjects involved in the study.

Data Availability Statement: Not applicable.

Acknowledgments: In this section, you can acknowledge any support given which is not covered by the author contribution or funding sections. This may include administrative and technical support, or donations in kind (e.g., materials used for experiments).

Conflicts of Interest: The authors declare no conflict of interest.

\section{References}

1. Maréchal, A.; Hart, K.; Baldock, D.; Erjavec, E.; Rac, I.; Vanni, F.; Mantino, F. Policy Lessons and Recommendations from the PEGASUS Project; Deliverable 5.4. H2020-Project Public Ecosystem Goods and Services from Land ManagementUnlocking the Synergies; Grant No. 633814; IEEP: London, UK, 2018. Available online: http://pegasus.ieep.eu/system/ resources/W1siZiIsIjIwMTgvMDMvMDEvMWVodjMwdmhzaV9ENS40X1BvbGljeV9sZXNzb25zX2FuZF9yZWNvbW1 lbmRhdGlvbnNfRklOQUwucGRmIl1d/D5.4\%20-\%20Policy\%20lessons\%20and\%20recommendations\%20FINAL.pdf?sha=4a2 85dbdf37d756d (accessed on 5 May 2021).

2. Pointereau, P.; Coulon, F.; Girard, P.; Lambotte, M.; Stuczynski, T.; Sánchez Ortega, V.; Del Rio, A. Analysis of Farmland Abandonment and the Extent and Location of Agricultural Areas that are Actually Abandoned or are in Risk to be Abandoned. In JRC Scientific and Technical Reports; European Commission, Joint Research Centre, Institute for Environment and Sustainability: Ispra, Italy, 2008.

3. Van Leeuwen, E.S.; Strijker, D.; Terluin, I. Regional Concentration and Specialisation in Agricultural Activities in EU-9 Regions (1950-2000). Eur. Spat. Res. Policy 2010, 17, 23-39. [CrossRef]

4. Vesco, P.; Kovacic, M.; Mistry, M.; Croicu, M. Climate variability, crop and conflict: Exploring the impacts of spatial concentration in agricultural production. J. Peace Res. 2021, 58, 98-113. [CrossRef]

5. Berry, W. The Unsettling of America: Culture and Agriculture; Counterpoint: Berkeley, CA, USA, 1977.

6. Dax, T.; Hellegers, P. Policies for Less-Favoured Areas. In CAP Regimes and the European Countryside, Prospects for Integration between Agricultural, Regional and Environmental Policies; Brouwer, F., Lowe, P., Eds.; CAB International: Wallingford, UK, 2000; pp. 179-197.

7. Baldock, D.; Beaufoy, G.; Brouwer, F.; Godeschalk, F. Farming at the Margins: Abandonment or Redeployment of Agricultural Land in Europe; Institute for European Environmental Policy (IEEP): London, UK; Agricultural Economics Research Institute (LEI-DLO): Hague, The Netherlands, 1996.

8. Crabtree, R.; MacDonald, D.; Hanley, N. Non-Market Benefits Associated with Mountain Regions. In Report for Highlands and Islands Enterprise and Scottish Natural Heritage; CJC Consulting: Aberdeen, UK, 2002.

9. Keenleyside, C.; Tucker, G.M. Farmland Abandonment in the EU: An Assessment of Trends and Prospects. In Report Prepared for WWF; Institute for European Environmental Policy: London, UK, 2010.

10. Organization for Economic Co-operation and Development (OECD). Cultivating Rural Amenities, An Economic Development Perspective; OECD Publishing: Paris, France, 1999. [CrossRef]

11. Jepsen, M.R.; Kuemmerle, T.; Müller, D.; Erb, K.; Verburg, P.H.; Haberl, H.; Vesterager, V.P.; Andrič, M.; Antrop, M.; Austrheim, G.; et al. Transitions in European land-management regimes between 1800 and 2010. Land Use Policy 2015, 49, 53-64. [CrossRef]

12. Perpiña Castillo, C.; Kavalov, B.; Diogo, V.; Jacobs-Crisioni, C.; Batista e Silva, F.; Lavalle, C. Agricultural Land Abandonment in the EU within 2015-2030. In JRC Report 113718; European Commission: Ispra, Italy, 2018.

13. O'Rourke, E. Drivers of Land Abandonment in the Irish Uplands: A Case Study. Eur. Countrys. 2019, 11, 211-228. [CrossRef] 
14. Ustaoglo, E.; Collier, M.J. Farmland abandonment in Europe: An overview of drivers, consequences and assessment of the sustainability implications. Environ. Rev. 2018, 26, 396-416. [CrossRef]

15. Lasanta, T.; Arnáez, J.; Pascual, N.; Ruiz-Flaño, P.; Errea, M.P.; Lana-Renault, N. Space-time process and drivers of land abandonment in Europe. Catena 2017, 149, 810-823. [CrossRef]

16. Benayas, J.M.; Martins, A.; Nicolau, J.M.; Schulz, J.J. Abandonment of agricultural land: An overview of drivers and consequences. Cab Rev. Perspect. Agric. Vet. Sci. Nutr. Nat. Resour. 2007, 2, 1-14. [CrossRef]

17. Chaudhary, S.; Wang, Y.; Dixit, A.M.; Khanal, N.R.; Xu, P.; Fu, B.; Yan, K.; Liu, Q.; Lu, Y.; Li, M. A Synopsis of Farmland Abandonment and Its Driving Factors in Nepal. Land 2020, 9, 84. [CrossRef]

18. Kristensen, S.B.P.; Busck, A.G.; van der Sluis, T.; Gaube, V. Patterns and drivers of farm-level land use change in selected European rural landscapes. Land Use Policy 2016, 57, 786-799. [CrossRef]

19. OECD/FAO/UNCDF. Adopting a Territorial Approach to Food Security and Nutrition Policy; OECD Publishing: Paris, France, 2016. [CrossRef]

20. European Coordination Via Campesina (ECVC). Food Sovereignty Now! A guide to Food Sovereignty; ECVC: Brussels, Belgium, 2018.

21. Levkoe, C.Z.; Brem-Wilson, J.; Anderson, C.R. People, power, change: Three pillars of a food sovereignty research praxis. J. Peasant Stud. 2019, 46, 1389-1412. [CrossRef]

22. Schuh, B.; Dax, T.; Andronic, C.; Derszniak-Noirjean, M.; Gaupp-Berghausen, M.; Hsiung, C.-H.; Münch, A.; Machold, I.; Schroll, K.; Brkanovic, S. The Challenge of Land Abandonment after 2020 and Options for Mitigating Measures. In Research for AGRI-Committee; European Parliament, Policy Department for Structural and Cohesion Policies, Directorate-General for Internal Policies: Brussels, Belgium, 2020. Available online: https:/ / bit.ly/39ElcFJ (accessed on 5 May 2021).

23. Prishchepov, A.V.; Schierhorn, F.; Löw, F. Unraveling the Diversity of Trajectories and Drivers of Global Agricultural Land Abandonment. Land 2021, 10, 97. [CrossRef]

24. Plieninger, P.; Draux, T.; Fagerholm, H.; Bieling, N.; Burgi, C.; Kizos, M.T. The driving forces of landscape change in Europe: A systematic review of the evidence. Land Use Policy 2016, 57, 204-214. [CrossRef]

25. Klein, J.A.; Tucker, C.M.; Nolin, A.W.; Hopping, K.A.; Reid, R.S.; Steger, C.; Grêt-Regamey, A.; Lavorel, S.; Müller, B.; Yeh, E.T.; et al. Catalyzing transformations to sustainability in the world's mountains. Earths Future 2019, 7, 547-557. [CrossRef]

26. Grêt-Regamey, A.; Brunner, S.H.; Kienast, F. Mountain ecosystem services: Who cares? Mt. Res. Dev. 2012, 32, S23-S34. [CrossRef]

27. MacDonald, D.; Crabtree, J.R.; Wiesinger, G.; Dax, T.; Stamou, N.; Fleury, P.; Gutierrez Lazpita, J.; Gibon, A. Agricultural abandonment in mountain areas of Europe: Environmental consequences and policy response. J. Environ. Manag. 2000, 59, 47-69. [CrossRef]

28. Santini, F.; Guri, F.; Gomez y Paloma, S. Labelling of Agricultural and Food Products of Mountain Farming. In JRC Working Papers JRC77119; Joint Research Centre: Sevilla, Spain, 2013.

29. Bentivoglio, D.; Savini, S.; Finco, A.; Bucci, G.; Boselli, E. Quality and origin of mountain food products: The new European label as a strategy for sustainable development. J. Mt. Sci. 2019, 16, 428-440. [CrossRef]

30. Sen, S.M.; Kansal, A. Integrating value-chain approach with participatory multi-criteria analysis for sustainable planning of a niche crop in Indian Himalayas. J. Mt. Sci. 2019, 16, 2417-2434. [CrossRef]

31. Brouwer, F.; van Rheenen, T.; Dhillion, S.S.; Elgersma, A.M. (Eds.) Sustainable Land Management, Strategies to Cope with the Marginalisation of Agriculture; Edward Elgar: Cheltenham, UK, 2008.

32. Copus, A.; Kahila, P.; Fritsch, M.; Dax, T.; Kovacs, K.; Tagai, G.; Weber, R.; Grunfelder, J.; Löfving, L.; Moodie, J.; et al. Final Report. European Shrinking Rural Areas: Challenges, Actions and Perspectives for Territorial Governance; ESPON 2020 project ESCAPE; Version 21/12/2020; ESPON EGTC: Luxembourg, 2020. Available online: https://www.espon.eu/sites/default/files/attachments/ ESPON\%20ESCAPE\%20Main\%20Final\%20Report.pdf (accessed on 5 May 2021).

33. Dax, T.; Copus, A. The Future of Rural Development. In Research for AGRI Committee-CAP Reform Post-2020—Challenges in Agriculture, Workshop Documentation; European Parliament, Directorate-General for Internal Policies, Ed.; Report IP/B/AGRI/IC/2015195; Policy Department B: Structural and Cohesion Policies, Agriculture and Rural Development: Brussels, Belgium, 2016; pp. 221-303. Available online: http:/ / www.europarl.europa.eu/RegData/etudes/STUD/2016/585898/IPOL_STU(2016)585898_ EN.pdf (accessed on 5 May 2021).

34. Payne, D.; Snethlage, M.; Geschke, J.; Spehn, E.M.; Fischer, M. Nature and People in the Andes, East African Mountains, European Alps, and Hindu Kush Himalaya: Current Research and Future Directions. Mt. Res. Dev. 2020, 40, A1-A14. [CrossRef]

35. Sitti, A.; Nagai, M.; Dailey, M.; Ninsawat, S. Exploring Land Use and Land Cover of Geotagged Social-Sensing Images Using Naive Bayes Classifier. Sustainability 2016, 8, 921. [CrossRef]

36. Pe'er, G.; Bonn, A.; Bruelheide, H.; Dieker, P.; Eisenhauer, N.; Feindt, P.H.; Hagedorn, G.; Hansjürgens, B.; Herzon, I.; Lomba, A.; et al. Action needed for the EU Common Agricultural Policy to address sustainability challenges. People Nat. 2020, 2, 305-316. [CrossRef]

37. Peeters, A.; Lefebvre, O.; Balogh, L.; Barberi, P.; Batello, C.; Bellon, S.; Gaifami, T.; Gkisakis, V.; Lana, M.; Migliorini, P.; et al. A Green Deal for implementing agroecological systems: Reforming the Common Agricultural Policy of the European Union. J. Sustain. Org. Agric. Syst. 2020, 70, 83-93. [CrossRef]

38. European Environment Agency (EEA). Landscapes in Transition, An Account of 25 Years of Land Cover Change in Europe; EEA Report No 10/2017; EEA: Copenhagen, Denmark, 2017. 
39. Gellrich, M.; Zimmermann, N.E. Investigating the regional-scale pattern of agricultural land abandonment in the Swiss mountains: A spatial statistical modelling approach. Landsc. Urban. Plan. 2007, 79, 65-76. [CrossRef]

40. Kuemmerle, T.; Levers, C.; Erb, K.; Estel, S.; Jepsen, M.R.; Müller, D.; Plutzar, C.; Stürck, J.; Verkerk, P.J.; Verburg, P.H.; et al. Hotspots of land use change in Europe. Environ. Res. Lett. 2016, 11, 1-14. [CrossRef]

41. Weissteiner, C.J.; Boschetti, M.; Böttcher, K.; Carrara, P.; Bordogna, G.; Brivio, P.A. Spatial explicit assessment of rural land abandonment in the Mediterranean area. Glob. Planet. Chang. 2011, 79, 20-36. [CrossRef]

42. Estel, S.; Kuemmerle, T.; Alcántara, C.; Levers, C.; Prishchepov, A.; Hostert, P. Mapping farmland abandonment and recultivation across Europe using MODIS NDVI time series. Remote Sens. Environ. 2015, 163, 312-325. [CrossRef]

43. Wilson, G.A.; Schermer, M.; Stotten, R. The resilience and vulnerability of remote mountain communities: The case of Vent, Austrian Alps. Land Use Policy 2018, 71, 372-383. [CrossRef]

44. Flury, C.; Huber, R.; Tasser, E. Future of Mountain Agriculture in the Alps. In The Future of Mountain Agriculture; Mann, S., Ed.; Springer: Berlin/Heidelberg, Germany, 2012; pp. 105-126. [CrossRef]

45. Haddaway, N.R.; Styles, D.; Pullin, A.S. Evidence on the environmental impacts of farm land abandonment in high altitude/mountain regions: A systematic map. Environ. Evid. 2014, 3, 17. [CrossRef]

46. Beilin, R.; Lindborg, R.; Stenseke, M.; Pereira, H.M.; Llausàs, A.; Slätmo, E.; Cerqueira, Y.; Navarro, L.; Rodrigues, P.; Reichelt, N.; et al. Analysing how drivers of agricultural land abandonment affect biodiversity and cultural landscapes using case studies from Scandinavia, Iberia and Oceania. Land Use Policy 2014, 36, 60-72. [CrossRef]

47. García-Martín, M.; Quintas-Soriano, C.; Torralba, M.; Wolpert, F.; Plieninger, T. Landscape Change in Europe; Chapter 2. In Sustainable Land Management in a European Context, Human-Environment Interactions 8. Cham; Weith, T., Bartkmann, T., Gaasch, N., Rogga, S., Strauß, C., Zscheischler, J., Eds.; Springer: Cham, Switzerland, 2020; pp. 17-36.

48. Massot, A.; Nègre, F. Research for AGRI Committee-The upcoming Commission's Communication on the Long-Term Vision of Rural Areas: Context and Preliminary Analysis; European Parliament, Policy Department for Structural and Cohesion Policies: Brussels, Belgium, 2020.

49. Terres, J.M.; Nisini Scacchiafichi, L.; Wania, A.; Ambar, M.; Anguiano, E.; Buckwell, A.; Coppola, A.; Gocht, A.; Nordstrom Kallstrom, A.; Pointereau, P.; et al. Farmland abandonment in Europe: Identification of drivers and indicators, and development of a composite indicator of risk. Land Use Policy 2015, 49, 20-34. [CrossRef]

50. Filho, W.L.; Mandel, M.; Al-Amin, A.Q.; Feher, A.; Chiappetta Jabbour, C. An assessment of the causes and con-sequences of agricultural land abandonment in Europe. Int. J. Sustain. Dev. World Ecol. 2016, 24, 554-560. [CrossRef]

51. Dax, T.; Wiesinger, G. Rural Amenities in Mountain Areas. In Sustainable Land Management, Strategies to Cope with the Marginalisation of Agriculture; Brouwer, F., van Rheenen, T., Dhillion, S.S., Elgersma, A.M., Eds.; Edward Elgar: Cheltenham, UK; Northampton, MA, USA, 2008; pp. 131-148.

52. Zukauskaite, E.; Trippl, M.; Plechero, M. Institutional Thickness Revisited. Econ. Geogr. 2017, 93, 325-345. [CrossRef]

53. Thorn, J.P.R.; Klein, J.A.; Steger, C.; Hopping, K.A.; Capitani, C.; Tucker, C.M.; Nolin, A.W.; Reid, R.S.; Chitale, V.S.; Marchant, R. A systematic review of participatory scenario planning to envision mountain socio-ecological systems futures. Ecol. Soc. 2020, 25, 6. [CrossRef]

54. Zavalloni, M.; D'Alberto, R.; Raggi, M.; Viaggi, D. Farmland abandonment, public goods and the CAP in a marginal area of Italy. Land Use Policy 2019, 104365. [CrossRef]

55. Maréchal, A. A Step Change in Policy to Deliver More Environmental and Social Benefits. In Policy Brief; Final Conference 7 February, EU-Project PEGASUS; IEEP: Brussels, Belgium, 2018.

56. European Commission. (COM(2018)392), Proposal for a Regulation of the European Parliament and of the Council Establishing Rules on Support for Strategic Plans to be Drawn Up by Member States under the Common Agricultural Policy (CAP Strategic Plans) and Financed by the European Agricultural Guarantee Fund (EAGF) and by the European Agricultural Fund for Rural Development (EAFRD) and Repealing Regulation (EU) No 1305/2013 of the European Parliament and of the Council and Regulation (EU) No 1307/2013 of the European Parliament and of the Council; European Commission: Brussels, Belgium, 2018.

57. Crabtree, R.; Dax, T.; Hovorka, G.; Köbler, M.; Delattre, F.; Vlahos, G.; Christopoulos, S.; Louloudis, L.; Viladomiu, L.; Rosell, J.; et al. Review of Area-based Less-Favoured Area Payments Across EU Member States. In Report for the Land Use Policy Group (LUPG) of the GB Statutory Conservation, Countryside and Environment Agencies, CJC Consulting; LUPG: Peterborough, UK, 2003.

58. Van Orshoven, J.; Terres, J.-M.; Tóth, T. (Eds.) Updated Common Bio-Physical Criteria to Define Natural Constraints for Agriculture in Europe. In JRC Scientific and Technical Reports; JRC, Institute for Environment and Sustainability: Ispra, Italy, 2012.

59. Patton, M.Q. Blue Marble Evaluation: Premises and Principles; Guilford Press: New York, NY, USA, 2020.

60. Rowe, A. Evaluation at the Nexus: Evaluating Sustainable Development in the 2020s. In Evaluating Environment in International Development, 2nd ed.; Uitto, J.I., Ed.; Routledge: Abingdon, UK, 2021; pp. 46-60.

61. Dax, T.; Copus, A. Final Report-Annex 13 How to Achieve a Transformation Framework for Shrinking Rural Regions; European Shrinking Rural Areas: Challenges, Actions and Perspectives for Territorial Governance, ESPON 2020 Project ESCAPE; Version 21/12/2020; ESPON EGTC: Luxembourg, 2020. Available online: https://www.espon.eu/sites/default/files/attachments/ ESPON\%20ESCAPE\%20Final\%20Report\%20Annex\%2013\%20-\%20Transformation\%20Framework.pdf (accessed on 5 May 2021).

62. Lambin, E.F.; Turner, B.L.; Geist, H.J.; Agbola, S.B.; Angelsen, A.; Bruce, J.W.; Coomes, O.T.; Dirzo, R.; Fischer, G.; Folke, C.; et al. The causes of land-use and land-cover change: Moving beyond the myths. Glob. Environ. Chang. 2001, 11, 261-269. [CrossRef] 
63. European Commission (EC). Peak Performance: New Insights into Mountain Farming in the European Union. In Commission Staff Working Document SEC(2009) 1724 Final; EC: Brussels, Belgium, 2009.

64. Dolton-Thornton, N. Viewpoint: How should policy respond to land abandonment in Europe? Land Use Policy 2021, $102,105269$. [CrossRef]

65. Hart, K.; Allen, B.; Lindner, M.; Keenleyside, C.; Burgess, P.; Eggers, J.; Buckwell, A. Land as an Environmental Resource. In Report Prepared for DG Environment, Contract No ENV.B.1/ETU/2011/0029; Institute for European Environmental Policy: London, UK, 2012.

66. O'Rourke, E.; Charbonneau, M.; Poinsot, Y. High nature value mountain farming systems in Europe: Case studies from the Atlantic Pyrenees, France and the Kerry Uplands, Ireland. J. Rural Stud. 2017, 46, 47-59. [CrossRef]

67. Pereira, H.M.; Navarro, L.M. (Eds.) Rewilding European Landscapes; Springer: Cham, Germany, 2015. [CrossRef]

68. Lefebvre, M.; Espinosa, M.; Gomez y Paloma, S.; Paracchini, M.L.; Piorr, A.; Zasada, I. Agricultural landscapes as multiscale public good and the role of the Common Agricultural Policy. J. Environ. Plan. Manag. 2015, 58, 2088-2112. [CrossRef]

69. Nigmann, T.; Dax, T.; Hovorka, G. Applying a social-ecological approach to enhancing provision of public goods through agriculture and forestry activities across the European Union. Stud. Agric. Econ. 2018, 120, 1-7. [CrossRef]

70. Tarolli, P.; Straffelini, E. Agriculture in Hilly and Mountainous Landscapes: Threats, Monitoring and Sustainable Management. Geogr. Sustain. 2020, 1, 70-76. [CrossRef]

71. Van der Sluis, T.; Pedroli, B.; Frederiksen, P.; Kristensen, S.B.P.; Gravsholt Busck, A.; Pavlis, V.; Cosor, G.L. The impact of European landscape transitions on the provision of landscape services: An explorative study using six cases of rural land change. Landsc. Ecol. 2019, 34, 307-323. [CrossRef]

72. Van der Zanden, E.H.; Carvalho-Ribeiro, S.M.; Verburg, P.H. Abandonment landscapes: User attitudes, alternative futures and land management in Castro Laboreiro, Portugal. Reg. Environ. Chang. 2018, 18, 1509-1520. [CrossRef] [PubMed]

73. Tarolli, P.; Preti, F.; Romano, N. Terraced landscapes: From an old best practice to a potential hazard for soil degradation due to land abandonment. Anthropocene 2014, 6, 10-25. [CrossRef]

74. Otero, I.; Marull, J.; Tello, E.; Diana, G.L.; Pons, M.; Coll, F.; Boada, M. Land abandonment, landscape, and biodiversity: Questioning the restorative character of the forest transition in the Mediterranean. Ecol. Soc. 2015, 20, 7. [CrossRef]

75. Martín-López, B.; Leister, I.; Cruz, P.L.; Palomo, I.; Grêt-Regamey, A.; Harrison, P.A.; Lavorel, S.; Locatelli, B.; Luque, S.; Walz, A. Nature's contributions to people in mountains: A review. PLoS ONE 2019, 14, e0217847. [CrossRef] [PubMed]

76. IEEP; Alterra. Reflecting Environmental Land Use Needs into EU Policy: Preserving and Enhancing the Environmental Benefits of "land Services": Soil Sealing, Biodiversity Corridors, Intensification/Marginalisation of Land Use and Permanent Grassland. In Final Report to the European Commission, DG Environment on Contract ENV.B.1/ETU/2008/0030; Institute for European Environmental Policy: London, UK, 2010.

77. Pfefferkorn, W.; Musović, Z. Analysing the Interrelationship between Regional Development and Cultural Landscape Change in the Alps. In Work Package 2 Report, REGALP; Regional Consulting: Wien, Austria, 2003.

78. Schirpke, U.; Tappeiner, U.; Tasser, E. A transnational perspective of global and regional ecosystem service flows from and to mountain regions. Sci. Rep. 2019, 9, 1-11. [CrossRef]

79. Meeus, J.H.A.; Wijermans, M.P.; Vroom, M.J. Agricultural Landscapes in Europe and their Transformation. Landsc. Urban. Plan. 1990, 18, 289-352. [CrossRef]

80. Van der Zanden, E.H.; Verburg, P.H.; Schulp, C.J.E.; Verkerk, P.J. Trade-offs of European agricultural abandonment. Land Use Policy 2017, 62, 290-301. [CrossRef] 